\title{
Effect of Pit Design and Soil Composition on Performance of Pyrus calleryana Street Trees in the Establishment Period
}

\author{
M.A. Rahman, P. Stringer, and A.R. Ennos
}

\begin{abstract}
Evapotranspirational cooling from urban trees is an effective way of reducing the urban heat island. However, the appropriate planting design to maximize the cooling benefit of street trees has not been widely examined. The current study investigated the growth and physiology of a commonly planted urban tree, Pyrus calleryana, in Manchester, UK. Trees were planted in April 2010 using three standard planting techniques: in a small open pit, and in small or large closed pits with non-compacted load-bearing soils and sealed with permeable paving slabs. The growth rate, leaf area index, and stomatal conductance were monitored over the next three growing seasons, together with chlorophyll analysis and fluorescence and leaf water potential, allowing researchers to determine tree health, water status, and evapotranspirational cooling. Trees in the open pits grew twice as fast as those in small covered pits and 1.5 times as fast as trees in large covered pits. Having significantly higher canopy density, canopy spread, and stomatal conductivity, the trees in the open pits provided up to $1 \mathrm{~kW}$ of cooling, compared to around 350 and $650 \mathrm{~W}$ by the small and large covered pits, respectively. Phenological observations, chlorophyll fluorescence, total chlorophyll, and foliar nutrient content confirmed that the trees in open pits were healthier. However, the leaf water potential of trees in the covered pits was less negative, showing that they were not suffering from water stress. Instead, limited aeration probably affected their root respiration and nutrient uptake, impairing their growth and physiological performance.

Key Words. Evapotranspiration; Manchester; Planting Design; Planting Pit; Pyrus calleryana; Root Aeration; Soil; United Kingdom; Urban Heat Island.
\end{abstract}

The role of urban trees in adapting cities to the urban heat island effect is well understood (Oke 1989; McPherson et al. 1997; Shashua-Bar and Hoffman 2000; Gill et al. 2007; James et al. 2009; Leuzinger et al. 2010; Peters et al. 2010; Armson et al. 2013). However, the appropriate planting design to maximize the shading and cooling benefits of urban street trees and to integrate them into the urban fabric amongst other intensely competitive land uses is still a big challenge. Along with poor quality soil, street trees in urban areas face both above- and belowground space competition (Grabosky and Bassuk 1995; Jim 2001). Greater soil volume with better aeration and drainage is very important for better root growth and the uptake of water and nutrients, allowing trees to achieve an optimum size and provide the ecosystem functions and benefits for which they are planted. Poor tree growth incurs a high level of maintenance input and drains resources that could otherwise be devoted to other aspects of urban forestry (Jim 2001). Gilbertson and Bradshaw (1990) reported that around $23 \%$ of newly planted trees in Liverpool, England, had died just after three years of planting, mainly due to limited soil volumes and increased soil compaction. In order to overcome this problem, some researchers have suggested mixing of different coarse matrix in the soil used for street tree planting to reduce the soil compaction and increase the load-bearing capacity. For example, Kristoffersen (1998) described the possibility of expanding the rooting zone of street trees by establishing a root-friendly, load-bearing growing medium under sealed pavement to carry light traffic. Grabosky and Bassuk (1995; 1996) also suggested rock-based structural soils for improving the rooting condition of urban street trees. Subsequently, several urban planners have started to incorporate stone or sand in varying proportions with soil, into major landscape improvement projects where the desired outcome is large, fast-growing trees.

However, there has been no published study that has investigated the long-term impact of these load-bearing soils or the impact of sealed pavements on tree growth and physiology. Grabosky et al. (2001) showed that street trees grown in structural and non-compacted soils had almost twice the shoot and root extension three years after planting compared to those grown in the standard pavement profiles. Studies have also shown that pavements can have significant impacts on the soil's physical characteristics, such as soil moisture and aeration (Morgenroth and Buchan 2009). If soil pore volume and soil pore continuity are reduced by compaction or sealing, roots cannot be supplied with oxygen (Herbauts et al. 1996; Horn et al. 2007). There are some studies that showed the effect of compacted soils on the growth and rooting abundance of different tree species (Randrup 1996; Smiley et al. 2006; Bartens et al. 2009; Rahman et al. 2011). However, little information is available on how the different types of paving sealant affect soil gas diffusivity or how urban trees react to soil aeration deficiencies. Weltecke and Gaertig (2012) have shown that relative gas diffusivity at tree planting sites with asphalt, flagstone, or cobblestone sealant was 10 times lower than at those sites without sealing. Moreover, there was no significant difference between completely sealed (asphalt) surfaces and "water permeable" surfaces with flagstone or cobblestone surfaces with gaps in between. Even if there is sufficient moisture in compacted soil underneath the pavement, it might act as a barrier to oxygen diffusion and lead to relatively anaerobic conditions in the deeper soil profile (Morgenroth and Buchan 2009). This condition may also affect the soil fauna and microbial activity, leading to nutrient defi- 
ciency. Consequently, tree roots at roadsides could be trapped between the concrete surface above and poor soil below (Jim 2001).

In this study, researchers compared three standard street planting techniques used in Manchester, UK. The first technique was the conventional method in which trees are planted in small cutout pits with topsoil. The other two techniques include trees planted with increased rooting volume and compaction reduction mechanisms and sealed with permeable sealing. Fifteen Pyrus calleryana 'Chanticleer' trees were planted in these three pit types. The objective of this study was to test the effectiveness of these pit designs and soil composition in respect to the growth, stress tolerance and cooling potentiality of a commonly planted street tree $P$. calleryana. To do this, researchers measured aspects of tree growth, stress levels, and transpiration on hot summers days over three growing seasons.

\section{METHODS}

\section{Study Site}

The study was carried out in Greater Manchester, UK, which is a large conurbation (population $2.5 \mathrm{~m}$ ) located in the northwest of England (Armson et al. 2012). It has a temperate maritime climate with a mean annual temperature of $9.8^{\circ} \mathrm{C}$ and annual precipitation of $806.6 \mathrm{~mm}$. Among the studied years, 2012 was significantly wetter $(1089 \mathrm{~mm}$ of rainfall $)$ than $2011(817 \mathrm{~mm})$ and 2010 (796 mm). Rainfall measurements were collected from the Whitworth Observatory $400 \mathrm{~m}$ north of the experimental street.

In conjunction with the Red Rose Forest, a community forestry group, researchers selected Dilworth Street $\left(53^{\circ} 27^{\prime} 47^{\prime \prime} \mathrm{N}, 2^{\circ} 14^{\prime} 3^{\prime \prime} \mathrm{W}\right)$ as the field site since it represents a true urban setting with residential buildings on one side and commercial buildings and a university parking lot on the other. The street is paved in black asphalt, bordered by concrete sidewalks (3-4 m wide) running from east (closed end - access to one of the University of Manchester parking lot) to west (Cecil Street), and is $7 \mathrm{~m}$ wide. It was also easily accessible for the subsequent measurements and comparatively secure. Fifteen Pyrus calleryana 'Chanticleer' root ball $(40 \mathrm{~cm} \times 45$ $\mathrm{cm})$ trees with circumference of $14-16 \mathrm{~cm}$ at $1 \mathrm{~m}$ from ground, and $4-4.5 \mathrm{~m}$ in height were planted in April 2010 in three types of pit installations. In the nursery (Barcham Trees PLC, Cambridgeshire, UK) bare-rooted trees were lifted as from the field and re-grown in $65 \mathrm{~L}$ containers for 12 months and only bottom branches were pruned. At the time of planting, all trees had comparable vigor and vitality. Type 1 (open) pit trees were planted in $1.5 \mathrm{~m}^{2}$ cutout pits in the pavement and filled with stone-free topsoil-a sandy loam in structure with $15 \%$ $18 \%$ clay, $20 \%-22 \%$ silt, and $60 \%-65 \%$ sand content but no additional measures were taken to reduce compaction. In Type 2 (small covered) pits, additional $50 \%$ coarse sand was added to topsoil in the pit to reduce the compaction, and the pit was sealed with permeable paving on top. Finally, to increase the rooting volume and reduce the compaction, an interlocking root cell system filled with topsoil was used in the bigger pit size (Type 3, large covered pit) (Table 1).

The schematic diagram of the three types of pit is shown in Figure 1 . The trees were all protected by steel tree guards 1800 $\mathrm{mm}$ high and $500 \mathrm{~mm}$ in diameter. In addition, a pair of treated softwood stakes $(2.4 \mathrm{~m}$ tall $\times 75 \mathrm{~mm}$ diameter $)$ were also installed in all three types of pits, and trees were secured to the stakes at approximately $1600 \mathrm{~mm}$ height using the twin stake and belt method. Trees were planted around 7-10 $\mathrm{m}$ apart from each other with the pit next to the curb. To reduce any bias in conditions, trees were planted in order in five groups, in each of which, trees growing in each type of pit was installed one after another. Nine trees were planted on the south side of the street, while the other six were planted on the north. At the north side, the buildings were far from the boundary line; therefore, trees were not shaded at any time of the day. However, along the south side, there were buildings that were approximately $7-8 \mathrm{~m}$ tall (two story) and 9-10 $\mathrm{m}$ distance from the boundary line, meaning that the trees were partially shaded at some point of the day.

Continuous monitoring of street level conditions was not possible; instead, sequences of diurnal measurements were made over three growing seasons. Observations were made during the following periods: April-November 2010, March-November 2011, and March-November 2012.

As part of aftercare, the contractor watered each tree with approximately $23 \mathrm{~L}$ of water at around 1 week intervals starting from the middle of April to the middle of May in 2010 and 2011. Water was given on the open surface of Type 1 pits and in the irrigation pipes for Type 2 and Type 3 pits.

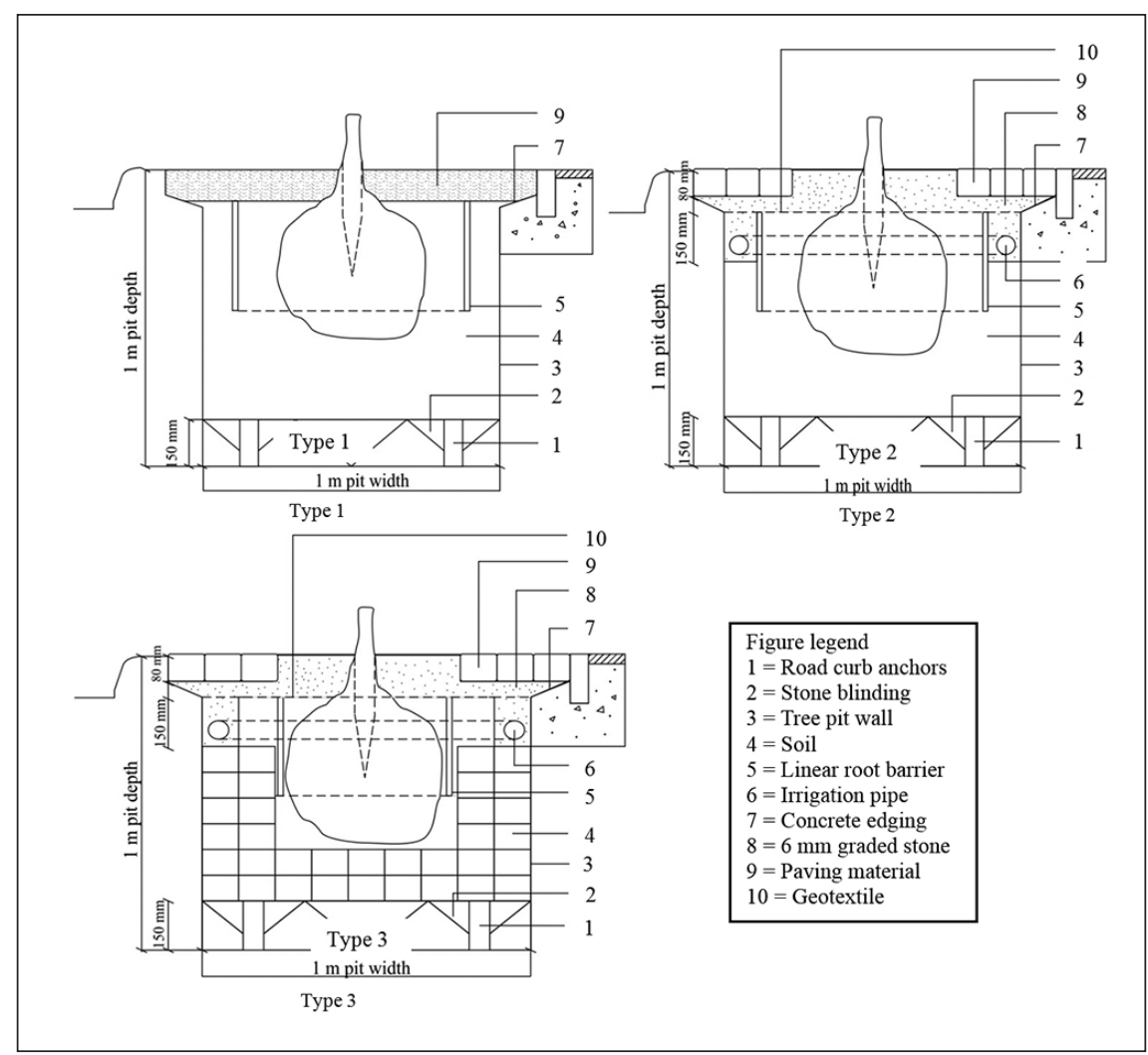

Figure 1. Cross-sectional design of the three pit types (adapted from tree planting design for Red Rose Forest, drawn by Ombler Iwanowski Architects). 
Table 1. Design of three types of planting pit used in the experiment.

\begin{tabular}{|c|c|c|c|}
\hline & Type 1 & Type 2 & Type 3 \\
\hline Pit dimension (m) & $1.2 \times 1.2 \times 1.0$ & $1.2 \times 1.2 \times 1.0$ & $1.2 \times 2.8 \times 1.0$ \\
\hline Soil composition & Topsoil & Urban soil ${ }^{\mathrm{z}}$ & $\begin{array}{l}\text { Special interlocking root cell system }{ }^{\mathrm{y}} \text { filled } \\
\text { with topsoil. }\end{array}$ \\
\hline Irrigation setup & none & $\begin{array}{l}\text { An irrigation pipe of } 895 \mathrm{~mm} \times 3 \mathrm{~m} \text { length, } \\
\text { outside of the root barrier at } 200-300 \mathrm{~mm} \text { depth } \\
\text { was installed. }\end{array}$ & Same as Type 2. \\
\hline Root barrier & $\begin{array}{l}\text { Only re-root } 300 \text { linear root barriers were } \\
\text { wrapped around top of root ball. }\end{array}$ & $\begin{array}{l}\text { With linear root barrier a terram } 3000 \text { permeable } \\
\text { geotextile layer was laid to stop upward } \\
\text { root growth. }\end{array}$ & Same as Type 2. \\
\hline Paving material & $\begin{array}{l}\text { Finished off with } 100 \mathrm{~mm} \text { depth of } \\
\text { composting mulch. }\end{array}$ & $\begin{array}{l}50 \mathrm{~mm} \text { laying course of } 6 \mathrm{~mm} \text { washed graded } \\
\text { aggregate was laid. Finally Marshall 'Priora'x } \\
\text { concrete block paving was used to seal the pit. }\end{array}$ & Same as Type 2. \\
\hline
\end{tabular}

${ }^{\mathrm{z}}$ Urban soil is a mix of $50 \%$ sand and $50 \%$ topsoil; overall texture is $10 \%-12 \%$ clay, $10 \%-12 \%$ silt, and $75 \%-80 \%$ sand content.

${ }^{y}$ Root cell system (Green-tech Ltd, York, UK): Each cell is $250 \mathrm{~mm} \times 250 \mathrm{~mm} \times 90 \mathrm{~mm}$ in size, made of recycled high-density polyethylene (HDPE) and has a loadbearing capacity of 80 tonnes per $\mathrm{m}^{2}$, each cell weighs $0.38 \mathrm{~kg}$ and has $92 \%$ empty space inside.

${ }^{x}$ Marshall 'Priora' concrete block: These are special zigzag bordered blocks with approximately $6 \mathrm{~mm}$ of gap between each block which allows $1.8 \mathrm{~L} \mathrm{~S}^{-1} \mathrm{~m}^{-2}$ water through them.

\section{Tree Growth and Phenology}

To compare the growth increment of trees, the total height of each tree was measured using a Suunto Clinometer, and bole height, $\mathrm{DBH}$, and canopy spreads in four directions measured biannually using a measuring tape between April 2010 and October 2012. The leaf area index (LAI) of trees was measured in May 2010 and another eight times over the summers between 11:30 am and 4:30 pm on warm sunny days at monthly intervals using an AccuPAR model LP-80 PAR/LAI Ceptometer (Decagon Devices, Washington, U.S.) along with other leaf physiological measurements. Bud break autumn coloration, and leaf fall were recorded according to Close et al. (1996) at the initiation of bud break, initiation of color change, peak color, and $100 \%$ leaf fall. Autumn coloration and leaf fall were recorded in 2010, 2011, and 2012; but bud break was recorded in 2011 and 2012 only.

\section{Leaf Physiology}

Physiological and meteorological measurements were made to investigate the water status and cooling potential of trees.

Predawn leaf water potential between 2:00 and 4:00 am, midday leaf water potential, and stomatal conductance between 12:00 noon and 4:00 pm, were measured on the same warm sunny days on eleven dates over the three growing seasons. Leaf water potential was measured using a pressure chamber technique (Digital Plant Water Potential Apparatus EL540-300 and EL540-305, ELE International, Hertfordshire, UK) and stomatal conductance was measured using a leaf porometer (model SC-1, Decagon Devices, Washington, U.S.). For each measurement, three sunlit leaves were used from the mid crown of each tree.

At the same time, meteorological measurements were also made that would enable researchers to calculate evapotranspiration. Air temperature and relative humidity were simultaneously measured in the tree shade, to reduce the radiation effect, $1.5 \mathrm{~m}$ above the ground using a Temperature and Humidity Datalogger - CEM DT-172 (accuracy +1\%) (Digital meter, Darwen, Lancashire, UK). Measurements were logged every five seconds and averaged over two minutes period for each record of air temperature and relative humidity. Leaf temperatures were also recorded using the porometer at the time of measur- ing the stomatal conductance. Atmospheric pressure data for each measurement day were recorded from published data of the meteorological station, Manchester Airport, UK. To check whether there was any significant difference in wind speed among the streets, wind speed at $1.5 \mathrm{~m}$ above ground was also measured (averaged over five minutes) using a handheld digital anemometer (Omega digital anemometer, model HHF92A).

The transpiration rates $\left(\mathrm{E}, \mathrm{mmol} \mathrm{m} \mathrm{m}^{-2} \mathrm{~s}^{-1}\right)$ of leaves were finally calculated from the stomatal conductance and meteorological data using Fick's law (Lambers et al. 1998):

$$
\mathrm{E}=\mathrm{g}_{\mathrm{v} \text { total }} \times\left(\mathrm{e}_{\text {leaf }}-\mathrm{e}_{\mathrm{a}}\right) / \mathrm{P}_{\mathrm{a}}
$$

where $\mathrm{g}_{\mathrm{v} \text { total }}$ is the total conductance to water vapor $\left(\mathrm{mmol} \mathrm{m} \mathrm{m}^{-2}\right.$ $\left.\mathrm{s}^{-1}\right), \mathrm{e}_{\text {leaf }}$ is the vapor pressure inside the leaf, which was assumed to be the saturation vapor pressure at leaf temperature, and $e_{a}$ is the vapor pressure of the atmosphere, calculated by multiplying the saturation vapor pressure at air temperature by the relative humidity of the air. $\mathrm{P}_{\mathrm{a}}$ is atmospheric pressure.

From Equation 1, the transpiration rate was converted to $\mathrm{g} \mathrm{m}^{-2} \mathrm{~s}^{-1}$ and multiplied by the latent heat of vaporization, which is 2.45 $\mathrm{kJ} \mathrm{g}^{-1}$, to calculate the energy loss per unit leaf area $\left(\mathrm{W} \mathrm{m}^{-2}\right)$. Energy loss per tree was then calculated according to Equation 2:

Energy loss per tree $=$ Energy loss per unit leaf area $\times$ $\mathrm{LAI} \times \mathrm{A}$

where LAI is the leaf area index of the tree and A is the crown area of the tree calculated from its crown diameter.

\section{Leaf Chlorophyll Fluorescence (Fv/Fm)}

Chlorophyll fluorescence has been used to provide a rapid and non-destructive diagnostic method for detecting and quantifying damage to the leaf photosynthetic apparatus in a variety of tree species in response to environmental stress (Percival 2004; Resco et al. 2008). Researchers measured chlorophyll fluorescence four times each over the growing seasons of 2011 and 2012 between May and September (due to technical difficulties, the study authors could not measure chlorophyll 
fluorescence in August 2012). Three leaves from the lower mid canopy of each tree were collected and shielded from ambient light to reach a dark adapted state (30 min. adaptation to the dark). Fv/Fm was measured as the ratio of maximal to variable fluorescence (Maxwell and Johnson 2000). Here, Fm is the maximum fluorescence and $\mathrm{Fv}$ was calculated by subtracting the minimum fluorescence (Fo) from Fm. Fv/Fm was measured by applying a saturating flash of white light provided by a quartz halogen lamp using PAM-2000 chlorophyll fluorometer (Heinz Walz, Effletrich, Germany).

\section{Leaf Chlorophyll Analysis}

The chlorophylls, Chlorophyll $a$ and Chlorophyll $b$ are the most important pigments for the conversion of light energy to stored chemical energy. Therefore, the content of these pigments can directly determine photosynthetic potential and primary production (Curran et al. 1990; Filella et al. 1995). Pigment content is closely related to plant stress and senescence (Gitelson et al. 2003). Chlorophylls were extracted from the same mature leaves collected for chlorophyll fluorescence by grinding leaf discs $\left(2.31 \mathrm{~cm}^{2}\right)$ in a mortar. Leaf discs from two leaves of each tree were extracted from the midpoint of the leaf next to the main leaf vein. Chlorophyll concentration was estimated at 663.6 and $645.6 \mathrm{~nm}$ wavelengths and corrected for light scattering at $750 \mathrm{~nm}$ in a spectrophotometer (USB-2000, Ocean Optics, Dunedin, U.S.) after extraction with $80 \% \mathrm{v} / \mathrm{v}$ aqueous acetone. Chlorophyll content values were recorded in eight terms according to Porra et al. (1989) on the same days as the chlorophyll fluorescence measurements.

\section{Foliar and Soil Nutrient Analysis}

As indicated in previous studies (Rahman et al. 2011; Rahman et al. in press), nutrient availability was assessed by investigating foliar levels of essential elements. Leaf samples were collected from the middle of the terminal shoot growth on August 15, 2011, and August 29, 2012. Leaves were air dried, ground with a mortar and pestle, and sieved with a 500-micron sieve. Total $\mathrm{N}$ was determined by dry combustion method using LECO TruSpecTM CN autoanalyzer (LECO Corporation). Determination of other essential elements viz. $\mathrm{P}, \mathrm{K}, \mathrm{Ca}, \mathrm{Mg}, \mathrm{Al}, \mathrm{B}, \mathrm{Co}, \mathrm{Cu}$, $\mathrm{Fe}, \mathrm{Mn}, \mathrm{Mo}, \mathrm{Ni}, \mathrm{Se}, \mathrm{Zn}$, and $\mathrm{Na}$ was carried out following standard procedure using inductively coupled plasma atomic emission spectroscopy (ICP-AES).

Soil analysis was carried out to determine soil $\mathrm{pH}$, organic carbon, and total $\mathrm{N}$ of soils used in three types of pits. Soil samples were collected from the top 15 $\mathrm{cm}$ of the soil, near the tree bases, from three pits of each type of pit on April 26, 2013, and air dried at room temperature. Stones, large roots, and other coarse fragments were removed using a $200 \mu \mathrm{m}$ sieve. Soil $\mathrm{pH}$ was determined using a $\mathrm{pH}$ meter (Mettler Toledo
FE20). Organic carbon contents were determined using the calorimetric method according to Motsara and Roy (2008). Total $\mathrm{N}$ was determined by the dry combustion method using LECO TruSpecTM CN autoanalyzer (LECO Corporation).

\section{Statistical Analysis}

Data were subjected to ANOVA and Tukey post hoc tests using SPSS V 20 software. Differences between groups were considered significant at $P<0.05$.

\section{RESULTS}

\section{Tree Growth and Phenology}

Trees in the open pits grew almost twice as fast as those grown in small covered pits and $50 \%$ faster than those grown in large covered pits (Figure 2a; Figure 2b). A one-way ANOVA showed significant differences between trees grown in different types of pits in height growth $[\mathrm{F}(2,27)=3.955 ; P<$ $0.05]$; in DBH growth $[\mathrm{F}(2,27)=17.691 ; P<0.001]$. Moreover, trees grown in open pits showed almost three times higher crown diameter increment than those grown in small covered pits (Figure 2c). Another one-way ANOVA showed significant differences between trees grown in three types of pits in crown diameter growth $[\mathrm{F}(2,12)=4.425 ; P<0.05]$ and a post hoc analysis showed that trees grown in open pits grew significantly higher in terms of height, $\mathrm{DBH}$, and crown diameter than those grown in small and large covered pits.

Trees grown in open pits also had more layers of leaves (Figure 3) compared to those grown in small and large covered pits. A two-way ANOVA showed significant differences in LAI of trees grown in three different types of pits between the planting pits $[\mathrm{F}(2,108)=6.103 ; P<0.01]$, between the time $[\mathrm{F}(8,108)=53.837 ; P<0.001]$, but no significant interaction between the planting pits and time. Post hoc tests showed that LAI of trees grown in open pits was higher compared to the trees grown in small and large covered pits. Moreover, post hoc analysis also showed that LAI was higher in mid to late summer compared to early summer.

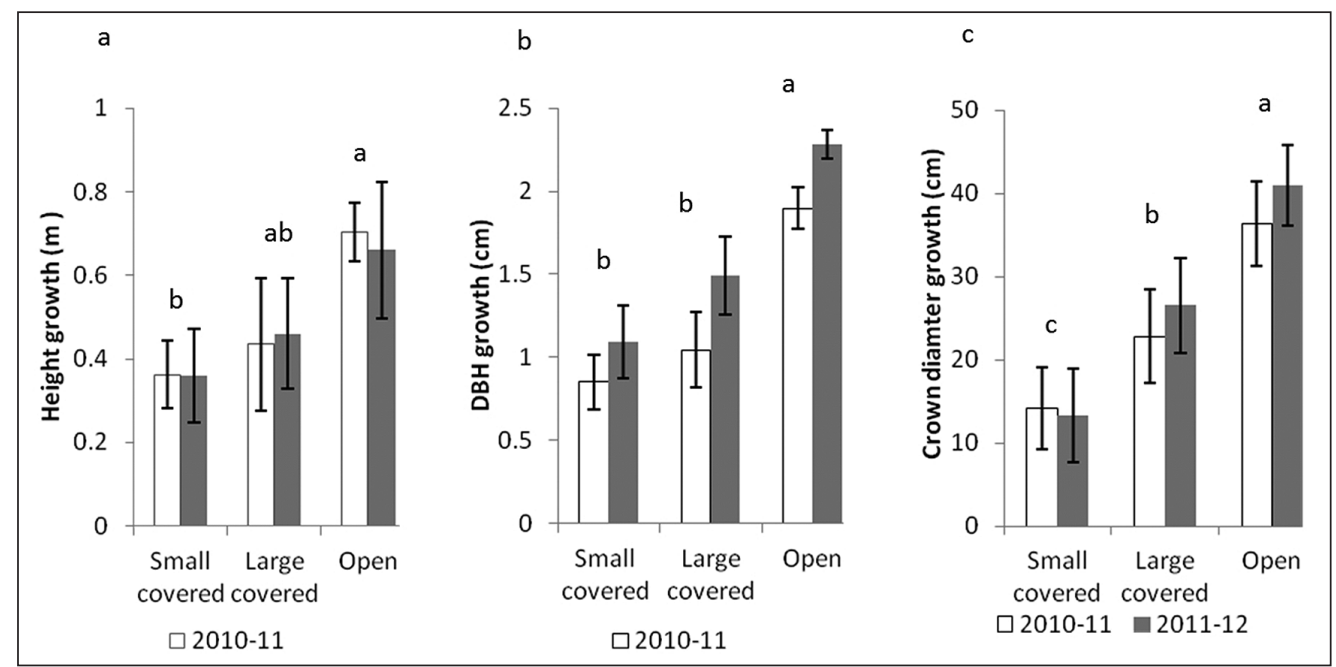

Figure 2. Annual growth rate in Pyrus calleryana trees grown in the three pit types in 2010-2012 ( $n=5$ ): (a) height, (b) DBH, (c) crown diameter increment. 
Trees grown in large covered and open pits finished breaking their buds around 5-8 days earlier, between March 29 and April 5 , compared to April 8-12, in the case of the trees grown in small covered pits (Table 2). Autumn color also peaked nearly two weeks later in large covered and open pits, around the third week of November versus the first week of November for small covered pits.

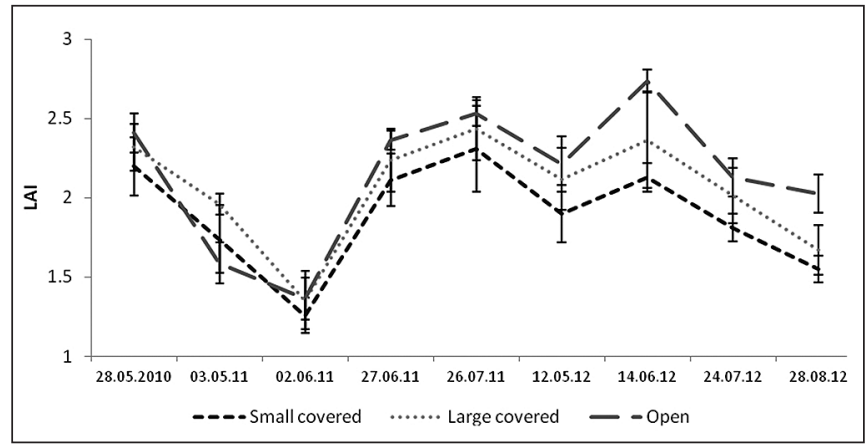

Figure 3. LAl of Pyrus calleryana trees grown in the three pit types in 2010-2012 $(n=5)$.

\section{Leaf Physiology}

There were also significant differences in midday leaf water potential (Figure 4a) and pre-dawn leaf water potential (Figure 4b) of trees grown in the three different types of pits and between different times when measurements were taken. A two-way ANOVA showed significant differences in midday leaf water potential between the planting pits $[\mathrm{F}(2,330)=4.722 ; P<0.05]$ and between times $[\mathrm{F}(10,330)=63.415 ; P<0.001]$, but no significant interaction between the planting pits and time. Post hoc tests showed that midday leaf water potential of trees grown in small and large covered pits were less negative compared to those grown in open pits. Post hoc tests also showed that midday leaf water potential was less negative towards the end of summer compared to early summer.

Another two-way ANOVA showed significant differences in predawn leaf water potential between the planting pits $[\mathrm{F}(2,332)$ $=6.008 ; P<0.01]$, between time $[\mathrm{F}(10,332)=80.373 ; P<0.001]$, and significant interaction between the planting pits and time $[\mathrm{F}$ $(20,332)=10.408 ; P<0.001]$. Post hoc tests showed that pre-dawn leaf water potential of trees grown in open pits and small covered pits were less negative than those grown in large covered pits. Post hoc test also showed that pre-dawn leaf water potential was less negative during midsummer compared to early and late summer.

Stomatal conductance of trees grown in the three types of planting pits was not significantly different for the first two measurement dates in 2010; however, the trees grown in open pits showed significantly higher stomatal conductivity throughout the measurement dates thereafter, except on May 21, 2012 (Figure 5). A two-way ANOVA showed significant differences between the planting pits $[\mathrm{F}(2,462)=40.316 ; P<$ $0.001]$, between times $[\mathrm{F}(10,462)=53.837 ; P<0.001]$, and a significant interaction between the planting pits and times $[\mathrm{F}$ $(20,462)=2.962 ; P<0.001]$. Post hoc tests showed that the stomatal conductance of trees grown in open pits was higher compared to trees grown in small and large covered pits. Moreover, post hoc analysis also showed that stomatal conductance was higher in late summer compared to early summer.

\section{Evapotranspirational Cooling}

There were large differences in evapotranspirational cooling provided by the trees grown in the three different types of planting pits and also between different times when measurements were taken (Figure 6). A two-way ANOVA showed significant differences in energy loss per tree between the planting pits $[\mathrm{F}(2,462)$ $=60.884 ; P<0.001]$, between times $[\mathrm{F}(10,462)=19.712 ; P$ $<0.001]$ and a significant interaction between the planting pits and time $[\mathrm{F}(20,462)=3.859 ; P<0.001]$. Post hoc analyses showed that the energy loss from trees grown in open pits was significantly higher than those grown in small and large covered pits, and energy loss from trees grown in large covered pits was higher than those grown in small covered pits. Moreover, post hoc analysis also showed that energy loss was higher during midsummer compared to the late or early summer and that the cooling ability of trees increased along with the age of the trees.

\section{Chlorophyll Fluorescence (Fv/Fm)}

There were also significant differences in the Fv:Fm ratio of trees grown in the three different types of planting pits and between different times when measurements were taken (Figure 7). A two-way ANOVA showed significant differences between the planting pits $[\mathrm{F}(2,84)=26.813 ; P<0.001]$ and significant differences between times $[\mathrm{F}(6,84)=26.299 ; P<$

Table 2. Phenological observations on Pyrus calleryana trees grown in the three pit types. Observations were carried out between mid-March and mid-December 2011 and 2012, and between mid-September and mid-December 2010.

\begin{tabular}{|c|c|c|c|c|c|c|c|c|}
\hline State & $\begin{array}{l}\text { 2nd week } \\
\text { March }\end{array}$ & $\begin{array}{l}\text { 1st week } \\
\text { April }\end{array}$ & $\begin{array}{l}\text { 3rd week } \\
\text { September }\end{array}$ & $\begin{array}{l}\text { 3rd week } \\
\text { October }\end{array}$ & $\begin{array}{l}1 \text { st week } \\
\text { November }\end{array}$ & $\begin{array}{l}\text { 3rd week } \\
\text { November }\end{array}$ & $\begin{array}{l}\text { 1st week } \\
\text { December }\end{array}$ & $\begin{array}{l}\text { 3rd week } \\
\text { December }\end{array}$ \\
\hline $\begin{array}{l}\text { Small covered pit } \\
\text { Bud break } \\
\text { Autumn color } \\
\text { Leaf fall }\end{array}$ & Started & $>60 \%$ & $\sim 12 \%$ & $\sim 40 \%$ & Peak & $>30 \%$ & $>80 \%$ & Completed \\
\hline $\begin{array}{l}\text { Large covered pit } \\
\text { Bud break } \\
\text { Autumn color } \\
\text { Leaf fall }\end{array}$ & Started & $>70 \%$ & $\sim 10 \%$ & $\sim 20 \%$ & $\sim 45 \%$ & $\begin{array}{l}\text { Peak } \\
>20 \%\end{array}$ & $>50 \%$ & $>90 \%$ \\
\hline $\begin{array}{l}\text { Open pit } \\
\text { Bud break } \\
\text { Autumn color } \\
\text { Leaf fall }\end{array}$ & Started & $>80 \%$ & $\sim 10 \%$ & $\sim 20 \%$ & $\sim 30 \%$ & $\begin{array}{l}\text { Peak } \\
>15 \%\end{array}$ & $>40 \%$ & $>80 \%$ \\
\hline
\end{tabular}




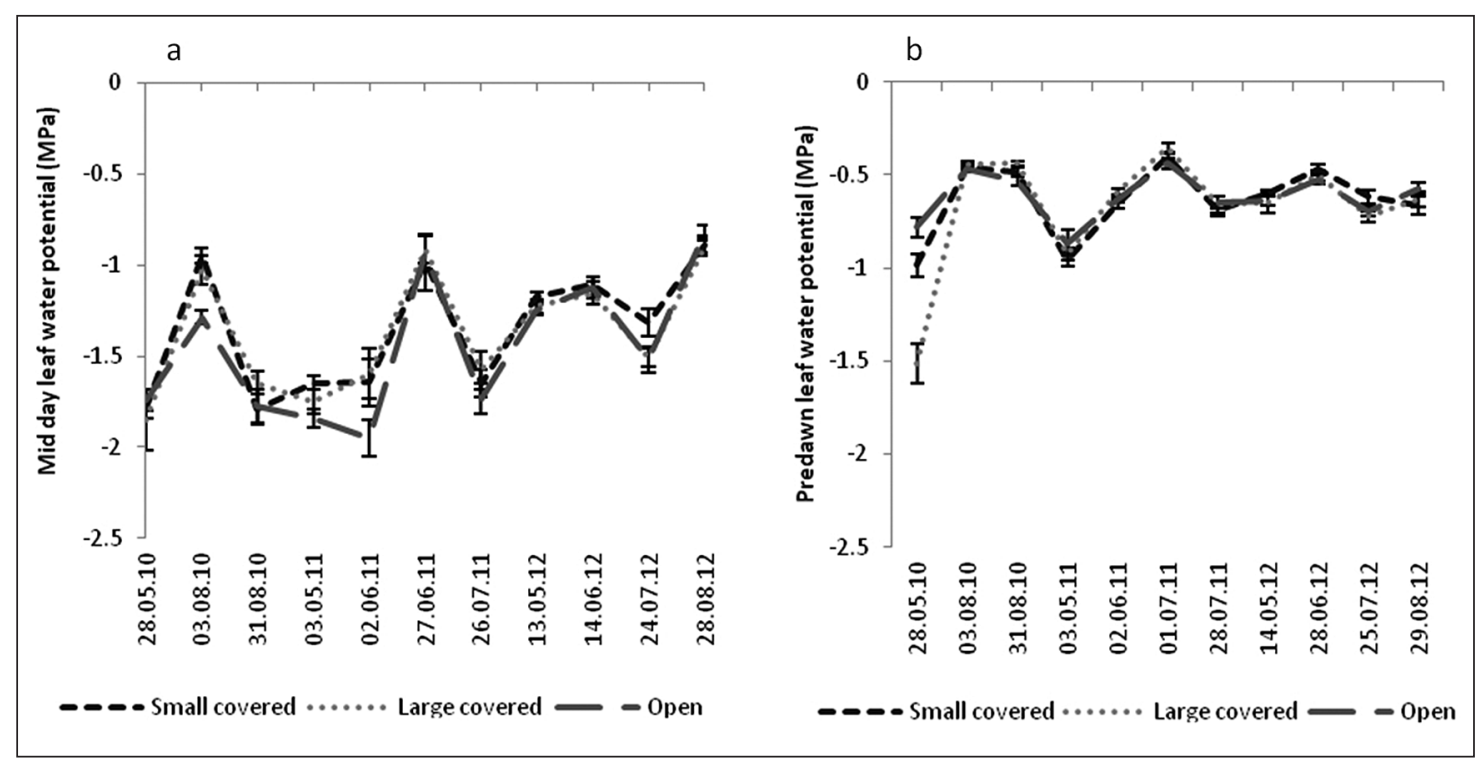

Figure 4. Leaf water potential of Pyrus calleryana trees grown in the three pit types in 2010-2012 $(n=5)$ : (a) midday, (b) pre-dawn.

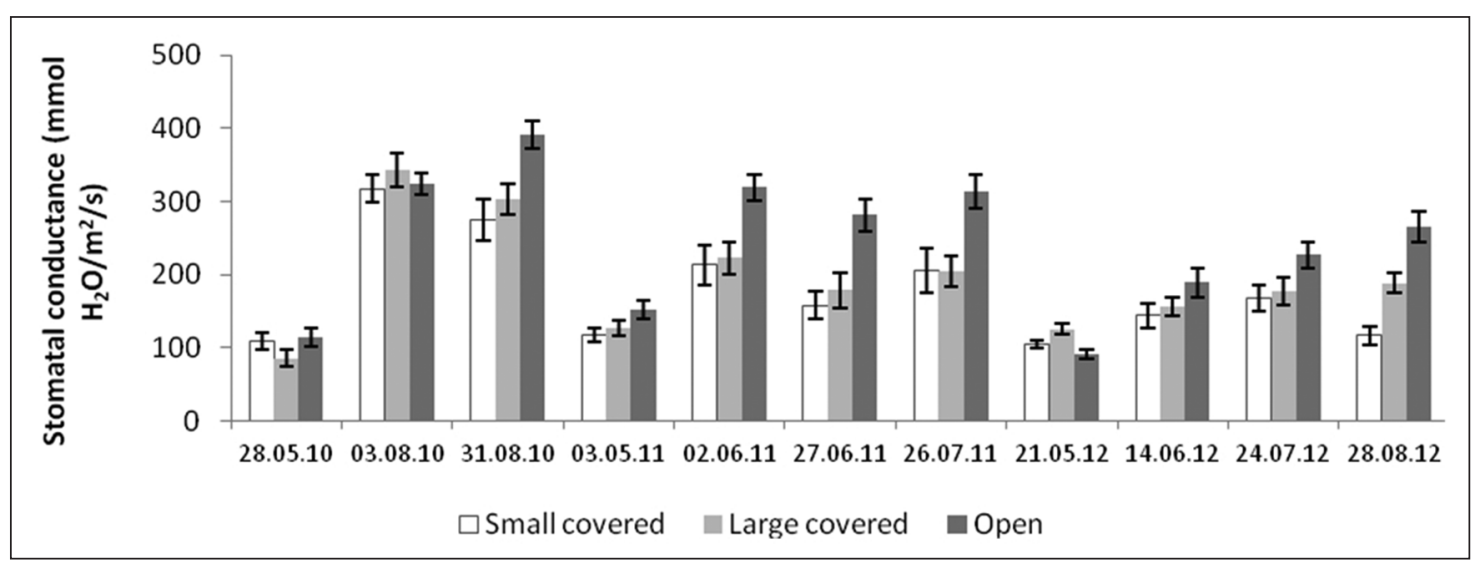

Figure 5. Stomatal conductance of leaves of Pyrus calleryana trees grown in the three pit types in 2010-2012 $(\mathrm{n}=5)$.

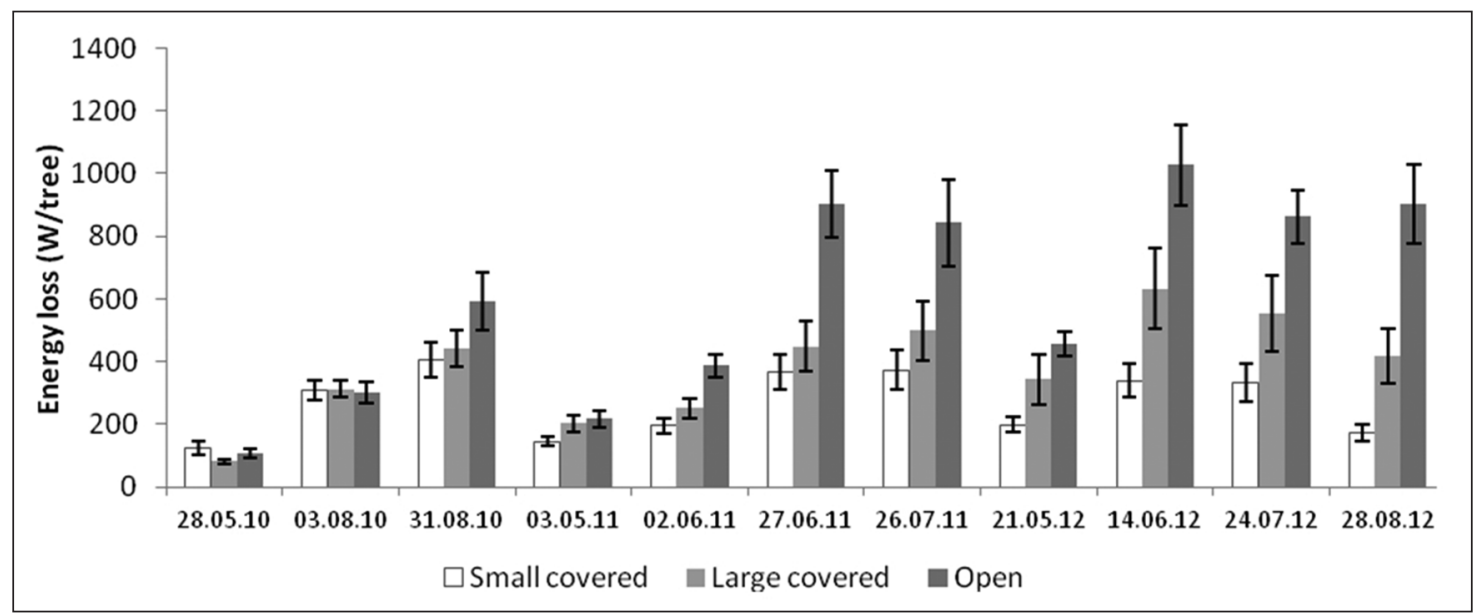

Figure 6. Evapotranspirational cooling of Pyrus calleryana trees grown in the three pit types in 2010-2012 $(n=5)$. 
0.001]. Post hoc tests showed that Fv:Fm ratio of trees grown in open and large covered pits were higher than those grown in small covered pits. Post hoc test also showed that the ratio was higher during mid to late summer compared to early summer.

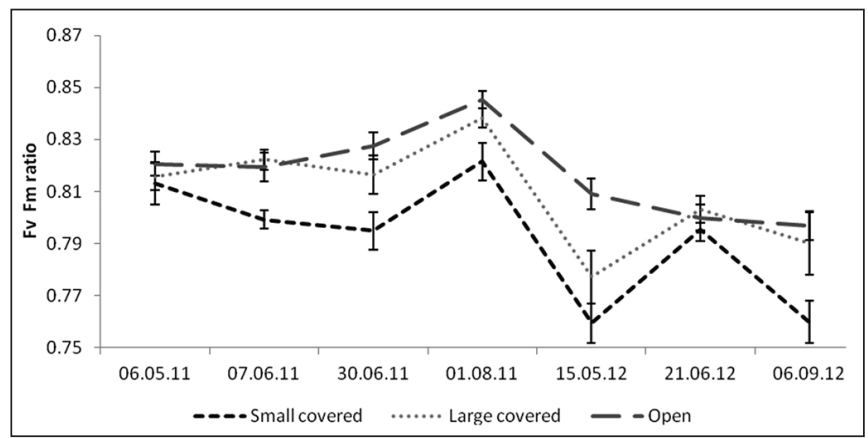

Figure 7. Chlorophyll fluorescence in leaves of Pyrus calleryana trees grown in the three pit types in 2011-2012 $(n=5)$.

\section{Total Chlorophyll}

Total chlorophyll content ( $a$ and $b$ ) of tree leaves showed significant differences between both planting pits and with time (Figure 8). A two-way ANOVA showed significant differences between the planting pits $[\mathrm{F}(2,96)=29.570 ; P<$ $0.001]$ and between time $[\mathrm{F}(7,96)=13.687 ; P<0.001]$; however, there was no significant interaction between the planting pits and time. Post hoc tests showed that total chlorophyll content of tree leaves grown in open pits was higher than both small and large covered pits and total chlorophyll content of tree leaves grown in large covered pits was higher than those grown in small covered pits. Moreover, post hoc test also showed that the total chlorophyll content of leaves of trees grown in three different types of pits were higher in mid to late summer compared to that of early summer.

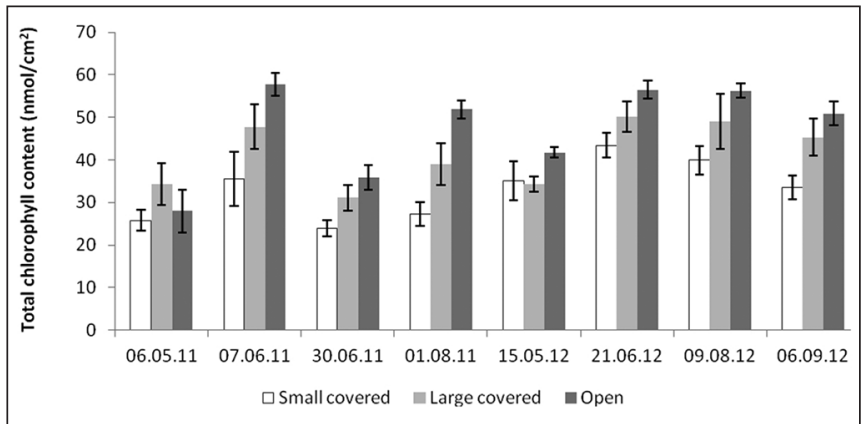

Figure 8. Total chlorophyll content $(a+b)$ of leaves of Pyrus calleryana trees grown in the three pit types in 2011-2012 ( $n=5)$.

\section{Foliar and Soil Nutrient Status}

There were differences in the nutrient status of several elements between trees grown in different types of planting pits (Table 3). One-way ANOVA showed foliar N, P, K, Fe, Mn, and $\mathrm{Zn}$ content of trees grown in open pits were significantly higher than those grown in small and large covered pits [F (2, $27)=11.386 ; P<0.001 ; \mathrm{F}(2,27)=6.058 ; P<0.01 ; \mathrm{F}(2,27)$ $=4.963 ; P<0.05 ; \mathrm{F}(2,27)=8.739 ; P<0.001 ; \mathrm{F}(2,27)=$ 3.386; $P<0.05$; and F $(2,27)=4.535 ; P<0.05$, respectively].
Soil $\mathrm{pH}$, organic carbon, and total $\mathrm{N}$ content of topsoil used in the open pits was also higher compared to the soil used in the small and large covered pits. Average soil pH of topsoil in the open pits (7.21) was significantly higher than the small covered (6.99) and large covered (6.98) pit $[\mathrm{F}(2,6)=8.22$; $P<0.05]$. Organic carbon and total nitrogen content of topsoil used in the open pits $(3.49 \%$ and $0.26 \%)$ was also significantly higher compared to the small covered pits $(2.21 \%$ and $0.17 \%)$ and large covered pits $(2.20 \%$ and $0.17 \%)[\mathrm{F}(2,6)=$ 25.709; $P<0.01 ; \mathrm{F}(2,6)=25.709 ; P<0.01$, respectively $]$.

\section{DISCUSSIONS}

The study has shown that there were significant differences in the rate of growth, morphology, and cooling effectiveness of trees grown in the three different planting pits. The tree in the open pits performed best; they grew twice as fast as trees in small covered pits and 1.5 times as fast as trees in large covered pits. The difference continued to increase over the growing seasons. In terms of morphology, they also showed almost three times more crown spread increment compared to those grown in small covered pits and 1.5 times more than those in large covered pits. Canopy density varied among the months surveyed, but trees grown in open pits showed significantly higher density throughout the experiment, and the trend was even more visible toward the end of the experiment. In general, with significantly higher stomatal conductivity, trees grown in open pits provided cooling more than double the amount by those grown in small covered pits and 1.5 times more than those grown in large covered pits.

It might be thought that these differences occurred because the paving on the covered planting pits reduced water infiltration into the pit, which would have caused them increased drought stress and reduced their nutrient uptake. However, both the midday and pre-dawn leaf water potential of the trees grown in the small covered pits were actually significantly less negative compared to those grown in large covered and open pits, showing that these trees were less water stressed. In contrast, the concentration of most important macronutrients such as N, $\mathrm{P}$, and $\mathrm{K}$, and micronutrients such as $\mathrm{Fe}, \mathrm{Mn}$, and $\mathrm{Zn}$ in the leaves of trees grown in open pits was significantly higher than those grown in small and large covered pits. Trees in the open pits also broke bud one week earlier and had leaf fall two weeks later compared to those grown in small covered pits. This suggests that the poor performance of the covered trees is due not to water deficit, but due to a lack of oxygen, which would hinder deeper rooting and ultimately affect the foliar investment and leaf gas exchange. This is certainly in line with the results of other studies (Morgenroth and Buchan 2009; Morgenroth 2011; Weltecke and Gaertig 2012). Morgenroth and Buchan (2009) and Morgenroth (2011) investigated the effect of pervious and impervious pavements on soil moisture content and aeration and in turn on the root growth of Platanus orientalis seedlings over two growing seasons. They found high moisture content underneath the pavement surface, irrespective of permeability, but a lack of aeration. Subsequently, the shallow root abundance was higher underneath the pavements but only in the case of unpaved plots did the seedlings achieve deeper rooting. It seems plausible that due to the sealing or reduced soil pore volume, the soil moisture content was higher in the upper soil layers, just as researchers of the present study found that tree planting pits with higher soil strength had increased soil moisture con- 
Table 3. Foliar nutrient status of Pyrus calleryana trees grown in the three pit types. Leaves were collected on August 15, 2011, and August 29, 2012 approximately 12-14 weeks after the full bloom.

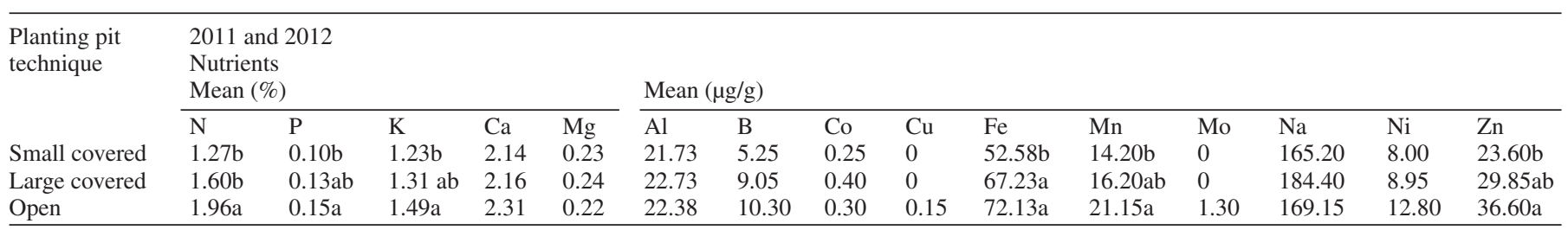

tent in the upper $20 \mathrm{~cm}$ of the soil profile (Rahman et al. 2011). Consequently, trees grown in small and large covered pits developed a shallow root system and showed reduced growth and physiological performance despite not being under water stress.

Leaf water potential corresponded generally well with rain events during the study. Following dry springs, both midday and pre-dawn leaf water potential of tree leaves grown in the three different types of pits were more negative. The sharp contrast in terms of planting techniques are that the trees grown in the open pits showed a significantly more negative midday leaf water potential than those in covered pits (small and large), but in terms of pre-dawn leaf water potential, trees grown in large covered pits were more negative. This might be due to the pavement effect, which reduces evaporation during the daytime but at night releases absorbed heat and evaporates more water from the soil relative to the open pit. Nevertheless, Nielsen et al. (2007) argued that soil hydrology is not always the driving mechanism of tree transpiration in street planting pits. Reduced soil pore volume and continuity due to sealing - in the case of both the small and large covered pits-might affect the root respiration and nutrient uptake of trees (Herbauts et al. 1996; Horn et al. 2007) leading towards reduced growth and stomatal conductivity. Moreover, topsoil in the open pits might have more opportunities to retain and accumulate nitrate by way of atmospheric deposition, although they are more vulnerable to leaching compared to the sealed pits. Lower $\mathrm{C}$ and $\mathrm{N}$ content of soils under paving surfaces were predictable and are in line with other research; including work by Raciti et al. (2012), who reported around $66 \%$ and $95 \%$ decrease in $\mathrm{C}$ and $\mathrm{N}$ content in the soil $(0-15 \mathrm{~cm})$ under impervious surfaces in New York City, New York, U.S.

Macronutrients, such as nitrogen, are also a dominant factor affecting the plant $\mathrm{Chl} a$ and are generally related to productivity (Filella et al. 1995). This might explain the higher chlorophyll content for trees grown in open pits. The higher $\mathrm{Chl} \mathrm{a+b}$ contents in the leaves of trees grown in open pits suggest that no damage had occurred in the chlorophyll biosynthetic pathways (De Nicola et al. 2011). Chlorophylls not only absorb light but also funnel the excitation energy from Photosystem I to Photosystem II, and the depression of Fv/Fm has consequently been used as an indicator of nutrient stress or imbalance (Kruskopf and Flynn 2006). Trees grown in the open pits also showed efficient use of light captured with their higher chlorophyll content in terms of better photochemical efficiency of PS II (Fv/Fm). Moreover, chlorophyll fluorescence of the trees grown in the open and large covered pits were within the specified range of the healthy, nonstressed, deciduous and evergreen trees (0.78-0.85) throughout the summer, indicating no sign of stress among those trees (Demmig and Bjorkman 1987; Maki and Colombo 2001; Percival 2004). Although there are reports that stomatal conductance is not directly determined by photosynthetic capacity (e.g., von Caemmerer et al. 2004), Matsumoto et al. (2005) showed that the stomatal conductance variability depended markedly on chlorophyll function and that the degree of dependence was almost equal to that on solar radiation or vapor pressure deficit.

All these factors together contributed towards a $40 \%$ increase in stomatal conductance of trees grown in open pits compared to those grown in small covered pits. Combined with a higher leaf area index and canopy spread, this meant that trees grown in open pits provided around $1 \mathrm{~kW}$ of cooling in June 2012. Although, the total energy loss per tree was calculated based on the transpiration rate of sunlit leaves, there is a chance of overestimation, since many of the leaves would have been shaded at the time of measurements. Ansley et al. (1994) compared the whole-tree transpiration rate based on porometer measurements with stem flow using sap flow gauges. They reported that the values were comparable; however, during the peak transpiration time (midday), porometer measurements might overestimate the whole-tree transpiration rate. But, considering the size of the canopy of those trees, it is arguable that most of the leaves would have sunlight at some point of the day.

Projecting the cooling ability of those trees grown in open pits over the next three growing seasons using existing stomatal conductivity and LAI but extending the canopy at the previous rate of growth gives a figure for cooling rate of around $7 \mathrm{~kW}$. This is comparable to a previous study in which $P$. calleryana trees were grown for six years in open pits with a non-compacted and sand-based soil (Rahman et al. 2011). Similarly, the study authors predict that the cooling ability of those $P$. calleryana grown in the small covered pits after three more growing seasons would be around $1.1 \mathrm{~kW}$ between June and August. This value is comparable, if somewhat smaller than the previous findings for $P$. calleryana grown in highly compacted pits six years after planting (Rahman et al. 2011; Rahman et al. in press). In this way, trees grown in small covered pits are losing the advantages of growing in non-compacted soil due to sealing. The experimental design for this study was opportunistic, based on three commonly used planting techniques by Red Rose Forest in Manchester, UK. There is a chance of confounding effect of soil composition and pit design. However, the consistency of the results across the studied years negated the advantages of better soil composition (both in terms of topsoil filled in root cell systems or mixing with sand) by the pit design. In this way, the study further emphasizes the importance of aeration, which might be equally or even more important for growth and the cooling ability of trees as soil compaction.

However, it must be stressed that these trees are all still very young in their establishment age, and the pattern might change as the trees mature, getting closer to their natural lifespan of 30-50 years. Once they start to break out of the confines of the pit, soil condition in the road site situation and the impervious pavement over root zones can confound other urban stresses on tree growth and physiology, since the trees on 
unrestricted rooting zones can extend as much as three times the dripline distance from the trunk (Gilman 1988). But impervious pavements are not equally deleterious to all species when grown in urban conditions, and researchers, such as Quigley (2004), have shown that early successional species, such as $P$. calleryana in the current study, might maintain a similar rate of growth rate after a longer period of establishment compared to the late-successional species. Future tree size in relation to available soil volume in the establishment stage is another consideration. Researchers such as Buhler et al. (2007) showed that trees planted in bigger sized pits $\left(>12 \mathrm{~m}^{2}\right)$ proved to be the best in terms of growth and vitality 15 years after planting in Copenhagen, Denmark, compared to trees planted in smaller sized pits with or without structural soil.

In conclusion, in this study, trees grown in open pits performed better in many ways than trees grown in large covered and especially compared to those grown in small covered pits. They grew faster, developed a wider crown with more leaf layers, had better stress tolerance, and showed better leaf physiological performance. As a result, they provided around double the amount of evapotranspirational cooling compared to trees planted in small covered pits and 1.5 times than those in large covered pits. However, the experimental site was in an uncrowded university-owned street, so there was not enough foot traffic to cause soil compaction in the open pits. The extra layer of composting mulch might also have helped the trees grown in open pits in their establishment period. If no compaction reduction measure is taken in case of open pits in busy streets, they might start losing their benefit of good soil aeration and reduce their growth and physiological performance. Therefore, large covered pits and other comparable methods might have an advantage in the long term if incorporated with techniques to increase soil aeration, such as sealing the surface with crisscrossed iron structures. The study authors' previous experiment showed better tree growth and physiological activities for $P$. calleryana trees grown in open cutout pits planted with sand-based soil (Rahman et al. 2011). Therefore, it might be a good idea to incorporate structural soil with an open surface or sealed with perforated structures for better growth and cooling performance of street trees. Finally, it would be worthwhile to monitor the effect on root growth and also the effect of ongoing climate change on different establishment methods in order to successfully manage urban ecosystems.

Acknowledgments. This project was supported by a doctoral grant funded by the Sustainable Consumption Institute (SCI), University of Manchester and the European Union INTERREG IVB fund as part of the VALUE project. Thanks are due to Mr. Keith Sacre of Barcham Trees, Mr. Andrew Hirons of Myerscough College, Mr. Griff Evans of Ombler Iwanowski Architects, Red Rose Forest and Dr. Giles Johnson of the University of Manchester for their cordial help during the experiment. Special thanks to Dr. David Armson, Dr. James Gardiner, and Mrs. Sonia Akter for all their help.

\section{LITERATURE CITED}

Ansley, R.J., W.A. Dugas, M.L. Heuer, and B.A. Trevino. 1994. Stem flow and porometer measurements of transpiration from honey mesquite (Prosopis glandulosa). Journal of Experimental Botany 45(275):847-856.

Armson D., M.A. Rahman, and A.R. Ennos. 2013. A comparison of the shading effectiveness of five different urban tree species. Arboriculture \& Urban Forestry 39(4):157-164.

Armson, D., P. Stringer, and A.R. Ennos. 2012. The effect of tree shade and grass on surface and globe temperatures in an urban area. Urban Forestry \& Urban Greening 11:245-255.

Bartens, J., S.D. Day, J.R. Harris, T.M. Wynn, and J.E. Dove. 2009. Transpiration and root development of urban trees in structural soil stormwater reservoirs. Environmental Management 44:646-657.

Buhler, O., P. Kristoffersen, and S.U. Larsen. 2007. Growth of street trees in Copenhagen with emphasis on the effect of different establishment concepts. Arboriculture \& Urban Forestry 33:330-337.

Close, R.E., P.V. Nguyen, and J.J. Kielbaso. 1996. Urban vs. natural sugar maple growth: I. Stress symptoms and phenology in relation to site characteristics. Journal of Arboriculture 22:144-150.

Curran, P.J., J.L. Dungan, and H.L. Gholz. 1990. Exploring the relationship between reflectance red edge and chlorophyll content in slash pine. Tree Physiology 7:33-48.

De Nicola, F., A. Alfani, and N. D'Ambrosio. 2011. Impact of the Mediterranean Urban Environment on Photosynthetic Efficiency of Quercus ilex Leaves. Water Air and Soil Pollution 220:151-160.

Demmig, B., and O. Bjorkman. 1987. Comparison of the effect of excessive light on chlorophyll fluorescence (77k) and photon yield of $\mathrm{O}_{2}$ evolution in leaves of higher-plants. Planta 171:171-184.

Filella, I., L. Serrano, J. Serra, and J. Penuelas. 1995. Evaluating wheat nitrogen status with canopy reflectance indexes and discriminantanalysis. Crop Science 35:1400-1405.

Gilbertson, P., and A.D. Bradshaw. 1990. The survival of newly planted trees in inner cities. Arboricultural Journal 14:287-309.

Gill, S.E., J.F. Handley, A.R. Ennos, and S. Pauleit. 2007. Adapting cities for climate change: The role of the green infrastructure. Built Environment 33:115-133.

Gilman, E.F. 1988. Prediction of root spread from trunk diameter and branch spread. Journal of Arboriculture 14:85-89.

Gitelson, A.A., Y. Gritz, and M.N. Merzlyak. 2003. Relationships between leaf chlorophyll content and spectral reflectance and algorithms for non-destructive chlorophyll assessment in higher plant leaves. Journal of Plant Physiology 160:271-282.

Grabosky, J., and N. Bassuk. 1995. A New Urban Tree Soil to Safely Increase Rooting Volumes Under Sidewalks. Journal of Arboriculture 21(4):187-201.

Grabosky, J., and N. Bassuk. 1996. Testing of structural urban tree soil materials for use under pavement to increase street tree rooting volumes. Journal of Arboriculture 22:255-263.

Grabosky, J., N. Bassuk, L. Irwin, and H. Van Es. 2001. Shoot and Root Growth of Three Tree Species in Sidewalks. Journal of Environmental Horticulture 19:206-211.

Herbauts, J., J. ElBayad, and W. Gruber. 1996. Influence of logging traffic on the hydromorphic degradation of acid forest soils developed on loessic loam in middle Belgium. Forest Ecology and Management 87:193-207.

Horn, R., J. Vossbrink, S. Peth, and S. Becker. 2007. Impact of modem forest vehicles on soil physical properties. Forest Ecology and Management 248:56-63. 
James, P., K. Tzoulas, M.D. Adams, A. Barber, J. Box, J. Breuste, T. Elmqvist, et al. 2009. Towards an integrated understanding of green space in the European built environment. Urban Forestry \& Urban Greening 8:65-75.

Jim, C.Y. 2001. Managing urban trees and their soil envelopes in a contiguously developed city environment. Environmental Management 28:819-832.

Kristoffersen, P. 1998. Designing urban pavement subbases to support trees. Journal of Arboriculture 24:121-126.

Kruskopf, M., and K.J. Flynn. 2006. Chlorophyll content and fluorescence responses cannot be used to gauge reliably phytoplankton biomass, nutrient status or growth rate. New Phytologist 169:525-536.

Lambers, H., F.S. Chapin, III, and T.L. Pons. 1998. Plant physiological ecology. Springer-Verlag New York, Inc.

Leuzinger, S., R. Vogt, and C. Korner. 2010. Tree surface temperature in an urban environment. Agricultural and Forest Meteorology 150:56-62.

Maki, D.S., and S.J. Colombo. 2001. Early detection of the effects of warm storage on conifer seedlings using physiological tests. Forest Ecology and Management 154:237-249.

Matsumoto, K., T. Ohta, and T. Tanaka. 2005. Dependence of stomatal conductance on leaf chlorophyll concentration and meteorological variables. Agricultural and Forest Meteorology 132:44-57.

Maxwell, K., and G.N. Johnson. 2000. Chlorophyll fluorescence - a practical guide. Journal of Experimental Botany 51:659-668.

McPherson, E.G., D. Nowak, G. Heisler, S. Grimmond, C. Souch, R. Grant, and R. Rowntree. 1997. Quantifying urban forest structure, function, and value: The Chicago urban forest climate project. Urban Ecosystems 1:49-61.

Morgenroth, J. 2011. Root growth response of Platanus orientalis to porous pavements. Arboriculture \& Urban Forestry 37:45-50.

Morgenroth, J., and G.D. Buchan. 2009. Soil Moisture and Aeration Beneath Pervious and Impervious Pavements. Arboriculture \& Urban Forestry 35:135-141.

Motsara, M.R., and R.N. Roy. 2008. Guide to Laboratory Establishment for Plant Nutrient Analysis. FAO, Rome.

Nielsen, C.N., O. Bühler, and P. Kristoffersen. 2007. Soil Water Dynamics and Growth of Street and Park Trees. Arboriculture \& Urban Forestry $33: 231-245$.

Oke, T.R. 1989. The Micrometeorology of the Urban Forest. Philosophical Transactions of the Royal Society of London Series B-Biological Sciences 324:335-349.

Percival, G.C. 2004. Evaluation of physiological tests as predictors of young tree establishment and growth. Journal of Arboriculture 30:80-91.

Peters, E.B., J.P. McFadden, and R.A. Montgomery. 2010. Biological and environmental controls on tree transpiration in a suburban landscape. Journal of Geophysical Research-Biogeosciences 115:G04006.

Porra, R.J., W.A. Thompson, and P.E. Kriedemann. 1989. Determination of accurate extinction coefficients and simultaneous-equations for assaying chlorophyll-a and chlorophyll-b extracted with 4 different solvents-verification of the concentration of chlorophyll standards by atomic-absorption spectroscopy. Biochimica Et Biophysica Acta 975:384-394.

Quigley, M.F. 2004. Street trees and rural conspecifics: Will long-lived trees reach full size in urban conditions? Urban Ecosystems 7:29-39.

Raciti, S.M., L.R. Hutyra, and A.C. Finzi. 2012. Depleted soil carbon and nitrogen pools beneath impervious surfaces. Environmental Pollution 164:248-251.
Rahman, M.A., D. Armson, and A. R. Ennos. in press. A comparison of the growth and cooling effectiveness of five commonly planted urban tree species. Urban Ecosystems.

Rahman, M.A., J.G. Smith, P. Stringer, andA.R. Ennos. 2011. Effect of rooting conditions on the growth and cooling ability of Pyrus calleryana. Urban Forestry \& Urban Greening 10:185-192.

Randrup, T.B. 1996. Urban soils as a growing medium for urban trees in: Urban forestry in the Nordic Countries. pp. 59. In: Proc. of a Nordic workshop on urban forestry, Danish Forest and Landscape Research Institute, Horsholm, Denmark.

Resco, V., D.D. Ignace, W. Sun, T.E. Huxman, J.F. Weltzin, and D.G. Williams. 2008. Chlorophyll fluorescence, predawn water potential and photosynthesis in precipitation pulse-driven ecosystems-implications for ecological studies. Functional Ecology 22:479-483.

Shashua-Bar, L., and M.E. Hoffman. 2000. Vegetation as a climatic component in the design of an urban street - An empirical model for predicting the cooling effect of urban green areas with trees. Energy and Buildings 31:221-235.

Smiley, E.T., L. Calfee, B.R. Fraedrich, and E.J. Smiley. 2006. Comparison of structural and noncompacted soils for trees surrounded by pavement. Arboriculture \& Urban Forestry 32:164-169.

von Caemmerer, S., T. Lawson, K. Oxborough, N.R. Baker, T.J. Andrews, and C.A. Raines. 2004. Stomatal conductance does not correlate with photosynthetic capacity in transgenic tobacco with reduced amounts of Rubisco. Journal of Experimental Botany 55:1157-1166.

Weltecke, K., and T. Gaertig. 2012. Influence of soil aeration on rooting and growth of the Beuys-trees in Kassel, Germany. Urban Forestry \& Urban Greening 11:329-338.

M.A. Rahman

Sustainable Consumption Institute (SCI)

Faculty of Life Sciences

University of Manchester

Manchester, M13 9PT, UK

mohammad.rahman-3@postgrad.manchester.ac.uk

Tel: 0044 (0)161306 4225

Fax: 0044 (0)161 2753938

P. Stringer

Red Rose Forest

Dock Office, Trafford Road

Salford Quays, Salford, M50 3XB, UK.

pete@redroseforest.co.uk

Tel: 00441618721660

Fax: 00441618721680

A.R. Ennos

Faculty of Life Sciences

University of Manchester

Manchester, M13 9PT, UK

roland.ennos@manchester.ac.uk

Tel: 0044 (0)161 2753848

Fax: 0044 (0)1612753938 
Zussamenfassung. Die evapotranspirationale Kühlung ausgehend von urbanen Bäumen ist ein effektiver Weg zur Reduzierung urbaner Hitzeinseln. Dennoch wurde ein entsprechendes Design der Pflanzung zur Maximierung des Kühleffektes noch nicht ausreichend untersucht. Die gegenwärtige Studie untersucht das Wachstum und die Physiologie eines oft gepflanzten urbanen Baumes Pyrus calleryana, in Manchester, UK. Im April 2010 wurden mit standardisierten Techniken Bäume gepflanzt: in schmalen offenen Pflanzlöchern und in kleinen oder großen geschlossenen Pflanzgruben mit unverdichtete Böden und mit wasserdurchlässiger Pflasterung. Die Wachstumsrate, Blattflächenindex und stomatale Leitfähigkeit wurden für die nächsten drei Wachstumsperioden aufgezeichnet, zusammen mit einer Chlorophyllanalyse, Fluoreszenz und Blattwasserpotential, was den Forschern ermöglichte, die Baumgesundheit, den Wasserstatus und die evapotranspirationale Kühlung zu bestimmen. Bäume in offenen Pflanzgruben wuchsen zweimal so schnell wie die Bäume in kleinen geschlossenen Gruben und anderthalbmal so schnell wie Bäume in großen geschlossenen Gruben. Bäume aus offenen Gruben mit signifikant höherer Kronendichte, Kronenausdehnung und stomataler Leitfähigkeit lieferten bis zu $1 \mathrm{~kW}$ Kühlung, verglichen mit um 350 und $650 \mathrm{~W}$ bei den kleinen und großen geschlossenen Pflanzgruben. Phenologische Beobachtungen, Chlorophyllfluoreszenz, totaler Chlorophyllgehalt und Nährstoffgehalt der Blätter bestätigten, dass Bäume in offenen Pflanzgruben gesünder waren. Trotzdem war das Blattwasserpotential der Bäume in geschlossenen Pflanzgruben weniger negativ, was darauf hinweist, dass die Bäume nicht unter Wasserstress leiden. Stattdessen konnte eine begrenzte Belüftung wahrscheinlich die Wurzelatmung und Nährstoffaufnahme mit Auswirkungen auf deren Wachstum und physiologischer Erscheinung beeinflussen.
Resumen. El enfriamiento por evapotranspiración del arbolado urbano es una forma efectiva de reducir la "isla de calor" urbana. Sin embargo, el diseño de la plantación adecuada para maximizar el beneficio de enfriamiento de árboles en las calles no se ha examinado ampliamente. El estudio investigó el crecimiento y la fisiología de un árbol urbano comúnmente plantado, Pyrus calleryana, en Manchester, Reino Unido. Los árboles fueron plantados en abril de 2010 mediante tres técnicas de plantación estándar: en una pequeña área abierta, en contenedores chicos y grandes con suelos no compactados y sellados con adoquines permeables. La tasa de crecimiento, índice de área foliar y la conductancia estomática fueron monitoreados durante las siguientes tres temporadas de crecimiento; junto con el análisis de clorofila, la fluorescencia y el potencial hídrico de las hojas. Lo anterior permite a los investigadores determinar la salud del árbol, el estado hídrico y el enfriamiento por evapotranspiración. Los árboles a cielo abierto crecieron dos veces más rápido que los de los contenedores pequeños cubiertos y 1,5 veces más rápido que los árboles en grandes contendores cubiertos; teniendo significativamente mayor densidad del dosel, cobertura y conductividad estomática los árboles a cielo abierto dando hasta $1 \mathrm{~kW}$ de enfriamiento, en comparación con alrededor de 350 y $650 \mathrm{~W}$ por los pequeños y grandes contendores cubiertos, respectivamente. Las observaciones fenológicas, fluorescencia de clorofila, clorofila total y el contenido de nutrientes foliares confirmó que los árboles a cielo abierto fueron más saludables. Sin embargo, el potencial hídrico de las hojas de los árboles en las cajas cubiertas fue menos negativo, mostrando que no sufrían de estrés hídrico. En cambio, la aireación limitada probablemente afecta la respiración de las raíces y la absorción de minerales, impidiendo su crecimiento y rendimiento fisiológico. 